\title{
SISTEM PENDUKUNG KEPUTUSAN PENDISTRIBUSIAN AIR BERSIH MENGGUNAKAN MOBIL TANGKI PADA PDAM KOTA MAKASSAR DENGAN MENGGUNAAN METODE TOPSIS
}

\author{
Billy Eden William Asrul*1, Sitti Zuhriyah ${ }^{2}$ \\ ${ }^{1}$ Teknik Informatika, STMIK Handayani Makassar, ${ }^{2}$ Sistem Komputer, STMIK Handayani, Makassar \\ Email: ${ }^{1}$ billy@handayani.ac.id, ${ }^{2}$ zuhriyah@handayani.ac.id \\ *Penulis Korespondensi
}

(Naskah masuk: 30 Oktober 2019, diterima untuk diterbitkan: 01 Februari 2021)

\begin{abstract}
Abstrak
PDAM Kota Makassar merupakan perusahaan daerah yang bertugas dalam pengelolaan dan pemenuhan kebutuhan air bersih bagi masyarakat di kota Makassar. Penyaluran air bersih yang dilakukan PDAM Kota Makassar masih belum mencakup keseluruhan wilayah Kota Makassar, ini disebabkan karena beberapa hal salah satu diantaranya debit air yang berkurang. Untuk mengatasi hal tersebut pemerintah kota Makassar melalui PDAM, melakukan pendistribusian air dengan cara pengantaran langsung ke rumah warga menggunakan mobil tangki. Proses penyaluran air PDAM mengalami kesulitan untuk menentukan daerah atau warga mana saja yang mendapatkan prioritas pengantaran air bersih, karena armada yang digunakan masih kurang. Mengatasi hal tersebut maka dibuat sebuah Sistem Pendukung Keputusan Pendistribusian Air Bersih, untuk memudahkan prioritas pengantaran air bersih. Metode penelitian melalui empat tahapan yaitu, pengenalan masalah, pengumpulan data, perancangan sistem, dan pengujian sistem, sedangkan metode yang digunakan adalah metode Topsis yang menggunakan 4 kriteria yakni; Peruntukkan, Jarak, Jumlah Kubik yang dipesan, dan Prediksi Jumlah pemakai. Peneliti memilih metode TOPSIS agar penentuan alternatif antara jarak ideal positif dan negatif lebih optimal. Hasil dari penelitian ini merupakan sistem pendukung keputusan pendistribusian air bersih PDAM yang berbasis web yang memudahkan penentuan prioritas penyaluran air bersih kepada masyarakat.
\end{abstract}

Kata kunci: Sistem Pendukung Keputusan, TOPSIS, PDAM

\section{DECISION SUPPORT SYSTEM FOR WATER DISTRIBUTION USING CAR TANK IN PDAM KOTA MAKASSAR USING TOPSIS METHOD}

\begin{abstract}
PDAM Makassar City is a regional company assigned to manage the fulfillment of clean water needs for citizens of Makassar City. Currently, the distribution of clean water still has not fully covered the entire area of Makassar City. The major causes of this situation is a dramatic decrease of the water debit in certain time. To overcome this problem, the government of Makassar city through PDAM, distributes water by direct delivery to the resident's houses using tank trucks. The process of channeling water from PDAM has difficulty in determining priority areas of delivery due to lack of the fleet. This research consists of four stages, namely: recognition of problems, data collection, system design, and system testing. While for the algorithm using the TOPSIS method that incorporate four criterias including the allotment, distance, amount of cubic, as well as predicted number of users. The TOPSIS method is chosen since the determination between the positive and negative ideal distances is more optimal. The results of this study is a web-based decision support system for clean water distribution of PDAM that helps to determine the priority of clean water distribution to the community in Makassar.
\end{abstract}

Keywords: Decision Support System, TOPSIS, PDAM

\section{PENDAHULUAN}

PDAM Kota Makassar adalah perusahaan daerah yang bertugas dalam pengelolaan dan pemenuhan kebutuhan air bersih bagi masyarakat kota Makassar. Penyaluran air bersih yang dilakukan
PDAM Kota Makassar masih belum mencakup keseluruhan Kota Makassar, oleh karena itu PDAM memanfaatkan mobil tangki untuk melayani daerahdaerah yang masih mengalami kekurangan air bersih. Pada proses penyaluran air bersih 
menggunakan mobil tangki yang dilakukan PDAM Kota Makassar, yaitu pembelian kupon yang di sediakan pihak PDAM Kota Makassar.

Pada pemesanan air bersih menggunakan mobil tangki dengan membeli kupon yang disediakan pihak PDAM, minat masyarakat Kota Makassar relatif tinggi, sedangkan jumlah armada mobil tangki terbatas, hanya berjumlah 9 unit dengan rincian kapasitas 4 Kubik berjumlah 5 unit dan kapasitas 5 kubik berjumlah 4 unit. Berdasarkan data laporan yang ditinjau pada periode Januari sampai dengan April, bahwa pemesanan mobil tangki air yang masuk berjumlah 1.922 pemesan, jika dirata-ratakan jumlah pemesan dalam satu hari berjumlah 16 pelanggan Namun dalam proses pemesanan maupun proses pendistribusiannya masih belum maksimal karena belum adanya sistem yang dapat memaksimalkan proses pengelolaan pendistribusian air.

Banyaknya masyarakat yang melakukan pemesanan air dengan menggunakan kupon dan setiap pemesanan tersebut memiliki kriteria yang berbeda-beda akan tetapi dalam pengelolaannya masih menggunakan buku besar. Hal ini menyebabkan keterlambatan dalam pendistribusian air menguunakan mobil tangki karena akan menyita waktu pada pengelolaan data pada bagian administrasi. Oleh karena itu PDAM Kota Makassar sangat membutuhkan sebuah Sistem Pendukung Keputusan yang membantu untuk penindak lanjutan pendistribusian air sehingga dengan adanya sistem tersebut dapat meningkatkan pelayanan pendistribusian air pada PDAM Kota Makassar.

Untuk mendukung sistem tersebut digunakan Metode Technique for Order Performance by Similarity to idea Solution (TOPSIS) yang sering digunakan dalam pengambilan keputusan multikriteria yang praktis (Kurniawan, 2018). Keputusan yang diambil melalui Metode ini adalah alternatif terbaik yang berdasarkan jarak terpendek dari solusi ideal positif dan jarak terjauh dari solusi ideal negative (Santiary et al., 2018). Tingkat kesulitan akan muncul ketik a banyak faktor yang dipertimbangkan dalam proses pengambilan keputusan.

Mengacu referensi diatas, maka penulis mengangkat judul Implementasi Metode TOPSIS pada Sistem Pendukung Keputusan Pendistribusian Air Bersih Menggunakan Mobil Tangki Pada PDAM Kota Makassar.

\section{METODE PENELITIAN}

Penelitian melalui lima tahapan penelitian yaitu,

a. Pengenalan Masalah

Penyaluran Air bersih pada PDAM kota Makassar melalui mobil tangki mengalami beberapa kendala dalam pelaksanaannya salah satunya adalah belum adanya sistem yang mengatur daerah apa saja yang menjadi prioritas dalam penyaluran air bersih. Hal ini disebabkan kurangnya armada mobil tangki, hanya berjumlah 9 unit dengan rincian kapasitas 4 Kubik berjumlah 5 unit dan kapasitas 5 kubik berjumlah 4 unit. Berdasarkan data laporan pemesanan mobil tangki air dalam hal ini di tinjau dari bulan Januari sampai dengan bulan April jumlah pemesananan mobil tangki yang masuk berjumlah 1.922 pemesan, jika dirataratakan jumlah pemesan dalam satu hari berjumlah 16 pelanggan Namun dalam proses pemesanan maupun proses pendistribusiannya masih belum maksimal karena belum adanya sistem yang dapat memaksimalkan proses pengelolaan pendistribusian air.

b. Pengumpulan Data

Penelitian ini mengumpulkan data primer melalui pengamatan dan wawancara langsung dengan narasumber dari PDAM sedangkan, sedangkan data sekunder diperoleh dari data yang sudah ada. Penelitian ini menggunakan 4 kriteria yang sudah ditetapkan oleh pihak PDAM, kriteria yang digunakan yaitu, peruntukkan, jarak, jumlah kubik, dan prediksi jumlah pemakai.

c. Perancangan Sistem

Pada tahapan ini dilakukan perancangan penelitian dengan menggunakan UML yang didesain secara terstruktur, sedangkan bahasa pemrograman menggunakan PHP, javascript, dan MySql untuk pengolahan database.

d. Implementasi Algoritma

Data yang sudah dikumpulkan akan diolah dan dianalisis dengan menggunakan metode TOPSIS untuk menentukan prioritas keputusan pengantaran air PDAM.

e. Pengujian Sistem

Sistem yang telah dibuat akan diuji langsung pada PDAM Kota Makassar, selain itu akan dilakukan evaluasi terhadap hasil penelitian dengan membandingkan hasil output dari hitung manual dan hasil pada sistem.

\section{TINJAUAN PUSTAKA}

\subsection{Sistem Pendukung Keputusan}

Sistem Pendukung Keputusan (SPK) adalah sebuah sistem berbasis komputer yang menggabungkan antara kemampuan intelektual seorang pakar dan kemampuan komputer yang mengolah data menjadi informasi dalam meningkatkan efektivitas pengambilan keputusan (Annur, 2018; Turban and Ting-Peng, 2008). Sistem ini mampu memecahkan masalah maupun kemampuan pengkomunikasian dalam kondisi semi terstruktur dan tak terstruktur dengan cara mengolah data dengan berbagai model secara interaktif sehingga dapat memberikan informasi yang bisa digunakan dalam membuat sebuah keputusan (Ningsih, Dedih and Supriyadi, 2017). 
SPK ini dibangun dalam rangka mengembangkan efektivitas dan produktivitas dalam menyelesaikan masalah dengan bantuan teknologi komputer dalam memberikan alternative pertimbangan dalam pengambilan keputusan akhir.

\subsection{Metode TOPSIS}

TOPSIS digunakan sebagai salah satu metode yang banyak digunakan dalam masalah pengambilan keputusan. TOPSIS membandingkan setiap alternatif dengan alternatif terbaik dan alternatif terburuk yang ada diantara alternatif-alternatif masalah sehingga dapat memberikan sebuah solusi dari sejumlah alternatif tersebut. Penelitian-penelitian sebelumnya banyak menggunakan metode TOPSIS, karena metode ini menggunakan jarak untuk melakukan perbandingan tersebut. TOPSIS mengasumsikan bahwa setiap kriteria akan dimaksimalkan ataupun diminimalkan. Maka dari itu nilai solusi ideal positif dan solusi ideal negatif dari setiap kriteria ditentukan, dan setiap alternatif dipertimbangkan dari informasi tersebut (Kristina, 2018).

TOPSIS menentukan solusi ideal positif dengan memaksimalkan kriteria manfaat dan meminimalkan kriteria biaya sedangkan solusi ideal negatif ditentukan dengan memaksimalkan kriteria biaya dan meminimalkan kriteria manfaat.

TOPSIS banyak digunakan karena konsepnya sederhana dan mudah dipahami, memiliki komputasi yang efisien dan mampu mengukur kinerja relatif dari alternatif - alternatif keputusan dalam bentuk matematis sederhana, selain itu TOPSIS dapat menggabungkan bobot relatif dari kriteria penting (Aqli, Ratnawati and Data, 2016). Adapun langkahlangkah dalam metode TOPSIS sebagai berikut:

1. Normalisasi Matriks

Alt $=\frac{(\text { Nilai alternatif perkriteria })}{(\text { Akar hasil pangkat perkriteria })}$

$$
R_{i j}=\frac{x_{i j}}{\sqrt{\sum_{i=1}^{m} x_{i j}^{2}}}
$$

Ket:

$x_{i j}=$ Nilai alternatif perkriteria

2. Pembobotan normalisasi matriks. Rumus yang digunakan sebagai berikut:

$y_{i j}=w_{i} r_{i j}$

3. Membuat matriks keputusan yang ternormalisasi terbobot, dengan rumus sebagai berikut:

$$
\begin{aligned}
& A^{+}=y_{1}^{+}, y_{2}^{+}, \ldots \ldots, y_{j}^{+} \\
& A^{-}=y_{1}^{-}, y_{2}^{-}, \ldots \ldots, y_{j}^{-}
\end{aligned}
$$

4. Menentukan matriks solusi ideal positif dan ideal negatif, rumus yang digunakan sebagai berikut:
5. Menentukan prioritas alternatif atau perangkingan.

\section{HASIL DAN PEMBAHASAN}

Penelitian ini, menggunakan metode TOPSIS untuk menentukan alternatif optimal dalam pengambilan keputusan prioritas pen distribusian air bersih dalam hal ini PDAM kota Makassar. Dalam penelitian ini menggunakan 4 kriteria dan 16 indikator yang ditentukan oleh pihak PDAM Kota Makassar. Sistem pendukung keputusan yang dibuat dalam penelitian ini berbasis Website, adapun rancangan sistem pada penelitian digambarkan dalam usecase diagram pada gambar 1 berikut,

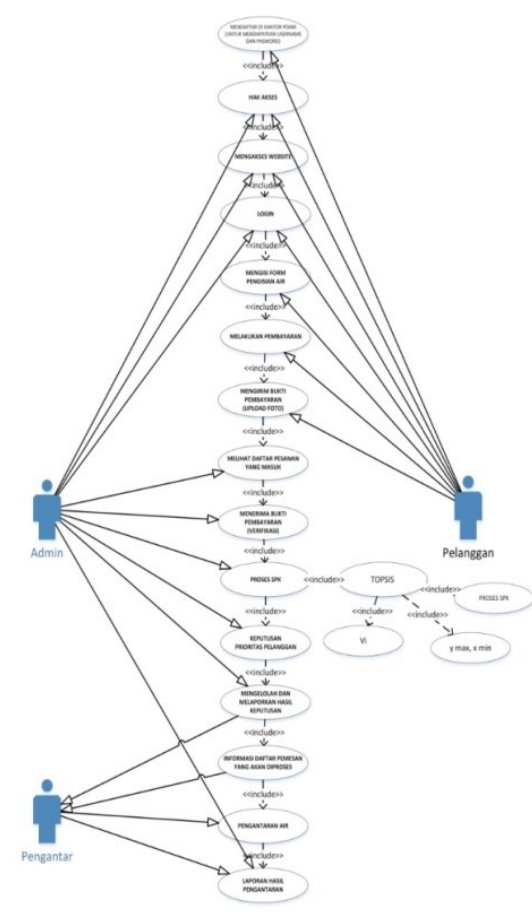

Gambar 1. Usecae Diagram

Berikut merupakan tabel kriteria dan indikator dari penelitian:

Tabel 1. Data Kriterian dan indicator Penilaian

\begin{tabular}{cccc}
\hline Peruntukan & Jarak & $\begin{array}{c}\text { Jumlah } \\
\text { Kubik }\end{array}$ & $\begin{array}{c}\text { Prediksi } \\
\text { Pemakai }\end{array}$ \\
\hline Pribadi & $>0 \mathrm{KM}-3$ & $4 \mathrm{k}$ & $5-20$ orang \\
KM & & $>50$ orang \\
Acara/Pesta & $>3 \mathrm{KM}-6 \mathrm{KM}$ & $8 \mathrm{k}$ & $>20-35$ orang \\
Komersial & $>6 \mathrm{KM}-$ & $5 \mathrm{k}$ & \\
& $10 \mathrm{KM}$ & & $>35-50$ Orang \\
\hline Sosial & $>10 \mathrm{KM}$ & $>8 \mathrm{k}$ &
\end{tabular}

Setelah itu, melakukan konversi nilai seperti pada tabel 2 berikut:

Tabel 2. Konversi Nilai Kriteria

\begin{tabular}{cccc}
\hline Peruntukan & Jarak & $\begin{array}{c}\text { Jumlah } \\
\text { Kubik }\end{array}$ & $\begin{array}{c}\text { Prediksi } \\
\text { Pemakai }\end{array}$ \\
\hline 2 & 4 & 1 & 1 \\
4 & 2 & 3 & 4 \\
1 & 2 & 2 & 2 \\
3 & 4 & 4 & 2 \\
\hline
\end{tabular}


38 Jurnal Teknologi Informasi dan Ilmu Komputer (JTIIK), Vol. 8, No. 1, Februari 2021, hlm. 35-40

\subsection{Implementasi Algoritma}

Data yang telah diperoleh tabel 1 dan tabel 2 diimplementasikan pada Metode TOPSIS dengan tahapan (Masruro and Wibowo, 2016; Chamid, 2016; Nugroho, Dewi and Marji, 2019; Mu'asyaroh and Mahmudy, 2016) sebagai berikut:

1. Normalisasi Matriks keputusan

Setelah menentukan bobot setiap kriteria, langkah selanjutnya adalah melakukan normalisasi Matriks. Dengan rumus sebagai berikut:

$$
\begin{aligned}
\text { Alt } & =\frac{(\text { Nilai alternatif perkriteria })}{(\text { Akar hasil pangkat perkriteria) }} \\
R_{i j}= & \frac{x_{i j}}{\sqrt{\sum_{i=1}^{m} x_{i j}^{2}}}
\end{aligned}
$$

Hasil dari proses perhitungan dapat dilihat pada tabel berikut:

Tabel 3. Hasil Perhitungan Normalisasi Matriks

\begin{tabular}{lcccc}
\hline Alternatif & \multicolumn{4}{c}{ Kriteria } \\
& K1 & K2 & K3 & K4 \\
\hline A001 & 0.3651 & 0.8 & 0.1826 & 0.2 \\
A002 & 0.7303 & 0.4 & 0.5477 & 0.8 \\
A003 & 0.1826 & 0.4 & 0.3651 & 0.4 \\
A004 & 0.5477 & 0.2 & 0.7303 & 0.4 \\
\hline
\end{tabular}

2. Pembobotan Normalisasi Matriks

Langkah selanjutnya adalah melakukan pembobotan matriks ternomalisasi dengan cara mengalikan nilai dari hasil tabel 3, dengan setiap bobot kriteria. Rumus sebagai berikut:

$$
y_{i j}=w_{i} r_{i j}
$$

Hasil dari perhitungan pembobotan sebagai berikut:

\begin{tabular}{lcccc}
\multicolumn{5}{c}{ Tabel 4. Matriks Terbobot } \\
\hline Alternatif & \multicolumn{4}{c}{ Kriteria } \\
& K1 & K2 & K3 & K4 \\
\hline A001 & 1.4606 & 2.400 & 0.548 & 0.6000 \\
A002 & 2.9212 & 1.200 & 1.643 & 2.4000 \\
A003 & 0.7303 & 1.200 & 1.095 & 1.200 \\
A004 & 2.1909 & 0.600 & 2.190 & 1.2000 \\
\hline
\end{tabular}

3. Menentukan Matriks Solusi Ideal

Langkah selanjutnya adalah menghitung Matriks solusi ideal, dengan menggunakan nilai pada tabel 4. Perhitungan matriks solusi ideal menggunakan persamaan (3) dan (4).

$A^{+}=y_{1}^{+}, y_{2}^{+}, \ldots \ldots, y_{j}^{+}$

$A^{-}=y_{1}^{-}, y_{2}^{-}, \ldots \ldots, y_{j}^{-}$

Tabel berikut merupakan hasil perhitungan

\begin{tabular}{|c|c|c|c|c|}
\hline \multirow{2}{*}{$\begin{array}{l}\text { Solusi } \\
\text { Ideal }\end{array}$} & \multicolumn{4}{|c|}{ Kriteria } \\
\hline & K1 & K2 & K3 & K4 \\
\hline Positif & 2.9212 & 2.4000 & 2.1909 & 2.4000 \\
\hline Negatif & 0.7303 & 0.6000 & 0.5477 & 0.6000 \\
\hline
\end{tabular}
matriks solusi ideal
Tabel 5. Matriks Solusi Ideal positf dan Negatif

4. Menentukan Jarak Matriks Solusi Ideal Positif dan Negatif.

Langkah selanjutnya adalah menentukan jarak matrik solusi ideal positif $\left(\mathrm{d}_{\mathrm{i}}^{+}\right)$dan matriks solusi ideal negatif $\left(\mathrm{d}_{\mathrm{i}}^{-}\right)$. Perhitungan jarak solusi ideal positif dan negatif menggunakan persamaan (4) dan (5)

$$
\begin{aligned}
& \mathrm{d}_{i}^{+}=\sqrt{\sum_{j=1}^{n}\left(y_{i j}-y_{i}^{+}\right)^{2}} \\
& \mathrm{~d}_{i}^{-}=\sqrt{\sum_{j=1}^{n}\left(y_{i j}-y_{i}^{-}\right)^{2}}
\end{aligned}
$$

Dengan $\mathrm{y}_{\mathrm{i}}^{+}$merupakan elemen dari matriks solusi ideal Positif dan $y_{i}^{-}$merupakan elemen dari matriks solusi ideal negatif. Hasil perhitungan Jarak matriks solusi ideal positif dan negatif dapat dilihat pada tabel 6 berikut.

Tabel 6. Matriks Jarak Solusi Ideal Positif dan Negatif

\begin{tabular}{ccc}
\hline \multirow{2}{*}{ Alternatif } & \multicolumn{2}{c}{ Jarak Solusi Ideal } \\
& $\mathbf{D}^{+}$ & $\mathbf{D}^{-}$ \\
\hline $\mathrm{A} 001$ & 0.9339 & 1.1233 \\
$\mathrm{~A} 002$ & 1.7703 & 0 \\
$\mathrm{~A} 003$ & 0.8729 & 1.5402 \\
$\mathrm{~A} 004$ & 1.2783 & 0.7071 \\
\hline
\end{tabular}

5. Menentukan Prioritas Alternatif atau Perangkingan

Hasil perhitungan pada tabel 6 digunakan untuk selanjutnya menentukan prioritas alternatif, dengan menggunakan persamaan (6),

$c_{i}=\frac{d_{i}^{-}}{d_{i}^{-}+d_{i}^{+}}$

Hasil dari perhitungan prioritas alternatif dapat dilihat pada tabel 7 berikut,

\begin{tabular}{cc}
\multicolumn{2}{c}{ Tabel 7. Hasil Prioritas Alternatif } \\
\hline Alternatif & Nilai \\
\hline A003 & 0.6383 \\
A001 & 0.5461 \\
A004 & 0.3562 \\
A002 & 0 \\
\hline
\end{tabular}

Setelah melakukan proses perhitungan manual dengan menerapkan metode TOPSIS, secara sistem yang dibuat, maka tampilan interfacenya sebagai berikut pada Gambar 2.

Gambar 2 merupakan tampilan awal pada sistem, dimana admin harus login terlebih dahulu sebelum menginput data yang diperlukan. 


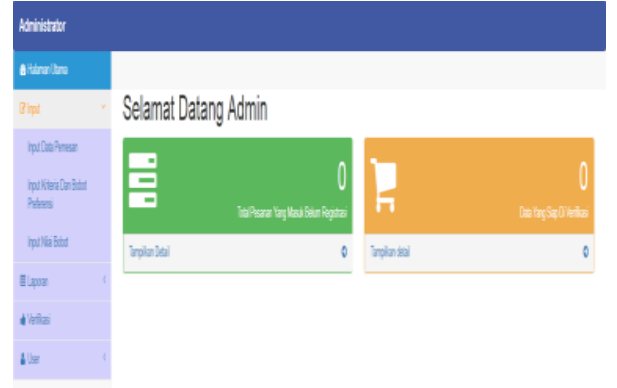

Gambar 2. Tampilan Login

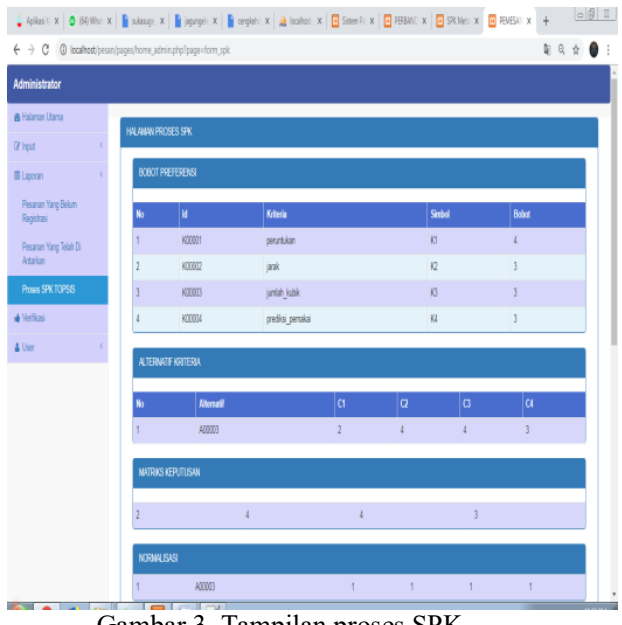

Gambar 3. Tampilan proses SPK

Gambar 3 merupakan tampilan perhitungan metode TOPSIS pada sistem.

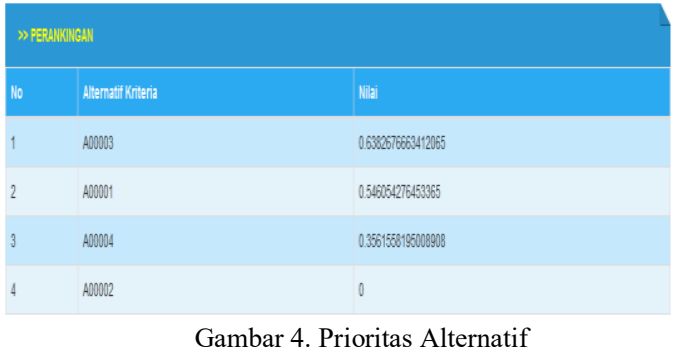

Gambar 4 merupakan tampilan prioritas alternatif. Hasil dari perhitungan prioritas terlihat A003 memiliki nilai tertinggi.

\subsection{Pembahasan}

Penelitian ini mengambil data dari PDAM Kota Makassar, berdasarkan tingkat kebutuhan masyarakat terhadap air bersih. Meskipun tingkat kebutuhan masyarakat terhadap air bersih sama besarnya, namun memiliki nilai yang berbeda setiap kriterianya. Hasil analisa secara manual dan sistem menunjukkan hasil yang sama, yaitu A003 menjadi pelanggan yang diprioritaskan untuk mendapatkan pengantaran air lebih dulu dibandingkan pelanggan yang lainnya.

Penelitian ini menggunakan empat kriteria dengan range nilai 1 sampai 4 , selain itu kriteria yang digunakan alah kriteria yang memiliki peluang yang sama dan saling berkaitan satu sama lainnya. Adapun kriteria yang dimaksud, yaitu kriteria 1 peruntukkan, pada kriteria ini terdiri dari 4 subkriteria yaitu pribadi, acara pesta, komersial dan sosial. Bobot tertinggi diberikan untuk peruntukkan Acara/pesta dengan bobot 4 . Kriteria 2 adalah Jarak, jarak yang dimaksud adalah jarak rumah pelanggan dengan PDAM, jarak terdekat mendapatkan bobot 4 . Kriteria 3 adalah Jumlah Kubik, pesanan dengan jumlah kubik terbanyak diberi bobot 4 . Kriteria 4 adalah Prediksi Jumlah pemakai, jumlah pemakai terbnyak yaitu di atas 50 diberi bobot 4 . Semua data kriteria dan pembobotan kriteria dalam penelitian ini berasal dari PDAM Kota Makassar yang kemudian data tersebut diolah dengan menggunakan metode TOPSIS. Proses pengolahan data dengan menggunakan TOPSIS melalui beberapa tahapan algoritma, mulai dari input nilai kriteria setiap alternatif, normalisasi matriks, pembobotan normalisasi matriks, sampai pada tahap terakhir yaitu penentuan prioritas alternatif. Pada penelitian ini, data tidak hanya diolah dengan menggunakan sistem tapi juga diolah secara manual dengan menggunakan perhitungan matematis yang akurat. Hasil yang diperoleh dari hasil pengolahan data baik secara manual maupun secara system diperoleh hasil yang sama, yaitu pelanggan dengan Kode A003 dengan nilai prioritas alternatif sebesar 0,6383 .

\begin{tabular}{llll}
\multicolumn{4}{c}{ Tabel 8. Data Pengantaran Suplai Air ke Pelanggan } \\
\hline No & $\begin{array}{c}\text { Kode } \\
\text { Pelanggan }\end{array}$ & \multicolumn{1}{c}{ Nama } & \multicolumn{1}{c}{ Alamat } \\
\hline 1 & A003 & Suhardiman & JL. Dr. Sam Ratulangi \\
2 & A004 & Nurhayati & Jl. Tupai \\
3 & A001 & A.Zulkarnain & Jl. Pettarani \\
4 & A002 & Rosmalawati & JL. Pettarani 2
\end{tabular}

Sumber data: PDAM Kota Makassar

Berdasarkan hasil Analisis data dengan menggunakan metode TOPSIS yang menjadi prioritas pengantaran pengantaran air adalah pelanggan dengan kode A003, jika dibandingkan dengan data dari PDAM kota Makassar pada tabel 8, hasil yang diperoleh sama yaitu pelanggan dengan kode A003. Tetapi ada data yang berbeda, jika dihitung uji akurasinya sebagai berikut:

$$
\begin{aligned}
\text { uji akurasi } & =\frac{3}{4} \times 100 \% \\
& =75 \%
\end{aligned}
$$

Dari uji akurasi didapat $75 \%$ tingkat kecocokan antara data yang dihasil oleh sistem dengan data yang ada pada PDAM, sehingga sistem ini dpat digunakan dalam penentuan prioritas pengantaran air pada PDAM kota Makassar. 


\section{KESIMPULAN}

Penerapan Metode TOPSIS pada Penelitian ini memberikan kemudahan bagi PDAM Kota Makassar dalam penyaluran air bersih menggunakan mobil tangki. Karena metode TOPSIS mampu memberikan prioritas alternatif yang ideal. Hasil yang diperoleh secara manual maupun hasil dari sistem didapatkan hasil yang sama dan telah divalidasi. Sehingga bisa dikatakan sistem pendukung keputusan Pendistribusian Air Bersih Menggunakan Mobil Tangki pada PDAM Kota Makassar dengan Menggunakan Metode TOPSIS untuk menentukan prioritas pendistribusian air bersih berjalan baik dan sesuai. Diharapkan sistem ini juga dapat diterapkan pada PDAM di wilayah yang mempunyai masalah dan karakter yang sama dengan PDAM kota Makassar.

\section{DAFTAR PUSTAKA}

ANNUR, H., 2018. Penempatan Bidan Di Desa Menggunakan Metode Analitycal Hierarchy Process ( AHP ). 10(7), pp.4451.

AQLI, I., RATNAWATI, D.E. and DATA, M., 2016. Sistem Rekomendasi Pemilihan Sekolah Menengah Atas (SMA) Sederajat Kota Malang Menggunakan Metode AHPELECTRE Dan SAW. Jurnal Teknologi Informasi dan Ilmu Komputer, 4(1), p.25.

CHAMID, A.A., 2016. Penerapan Metode Topsis Untuk Menentukan Prioritas Kondisi Rumah. Simetris: Jurnal Teknik Mesin, Elektro dan Ilmu Komputer, 7(2), p.537.

KRISTINA, T., 2018. Sistem Pendukung Keputusan Dengan Menggunakan Metode TOPSIS Untuk Pemilihan Lokasi Pendirian Grosir Pulsa. Paradigma, 20(1), pp.8-12.

KURNIAWAN, D.E., 2018. Pemilihan Wisata Menggunakan Technique for Order Preference By Similarity To Ideal Solution (Topsis) Dengan Visualisasi Lokasi Objek. Klik - Kumpulan Jurnal Ilmu Komputer, $5(1)$, p. 75 .

MASRURO, A. and WIBOWO, F.W., 2016. Intelligent Decision Support System for Tourism Planning Using Integration Model of K-Means. (1), pp.52-57.

MU'ASYAROH, F.L. and MAHMUDY, W.F., 2016. Implementasi Algoritma Genetika Dalam Optimasi Model AHP dan Topsis Untuk Penentuan Kelayakan Pengisian Bibit Ayam Broiler di Kandang Peternak. Jurnal Teknologi Informasi dan Ilmu Komputer, 3(4), p.226.

NINGSIH, E., DEDIH, D. and SUPRIYADI, S., 2017. Sistem Pendukung Keputusan Menentukan Peluang Usaha Makanan Yang Tepat Menggunakan Weighted Product (Wp) Berbasis Web. ILKOM Jurnal Ilmiah,
9(3), p.244.

NUGROHO, U.A., DEWI, R.K. and MARJI, 2019. Implementasi TOPSIS pada Sistem Rekomendasi Tempat Pembelian Sayur Organik di Malang Berbasis Lokasi. 3(4), pp.3728-3732.

SANTIARY, P.A.W., CIPTAYANI, P.I., SAPTARINI, N.G.A.P.H. and SWARDIKA, I.K., 2018. Sistem Pendukung Keputusan Penentuan Lokasi Wisata dengan Metode TOPSIS. 5(5), pp.621-628.

TURBAN, E.J.E.A. and TING-PENG, 2008. Decision Support Systems and Clinical Innovation. Getting Research Findings into Practice: Second Edition, pp.123-137. 